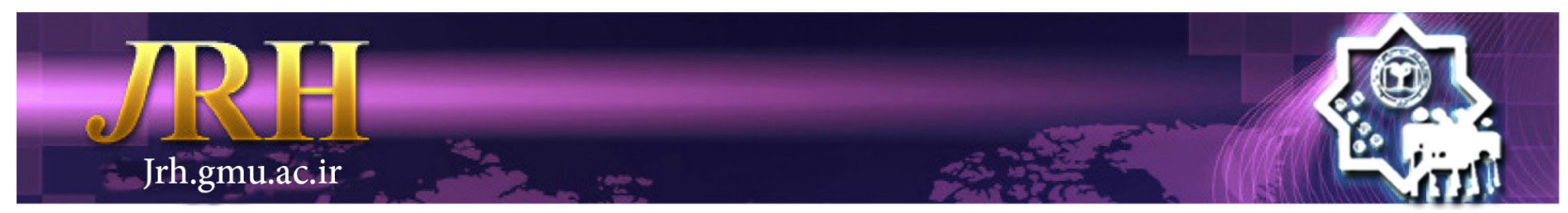

\title{
Gender inequality of employed women caused to health complications
}

Samira Shahbazzadegan ${ }^{1}$, Mozhgan Shahbazzadegan², Malihe Pishvaei $^{3}$

\author{
Journal of Research \& Health \\ Social Development \& Health Promotion \\ Research Center \\ Vol. 8, No.3, May \& Jun 2018 \\ Pages: 196- 197 \\ DOI: $10.29252 / j r h .8 .3 .196$ \\ Letter to Editor
}

1. Department of Reproductive Health and Midwifery, School of Nursing and Midwifery, Ardabil University of Medical Sciences, Ardabil, Iran

2. Master of Criminal Justice and Criminology, Scieneces Research Branch Islamic Azad University, Tehran, Iran

3. Correspondence to: Social Development \& Health Promotion Research Center, Gonabad University of Medical Sciences, Gonabad, Iran Email: masterpiece704@gmail.com

Received: 29 Oct 2017

Accepted: 24 Feb 2018

How to cite this article: Shahbazzadegan S, Shahbazzadegan M, Pishvaei M. Gender inequality of employed women caused to health complications. J Research \& Health2018; 8(3): 196- 197

\section{Dear Chief in Editor}

Gender equality means the enjoyment to rights, opportunities, and life chances has not been governed or limited by the gender. One of the issues highlighted in international human rights is the elimination of gender-based discrimination and the need for equality between men and women in the human society. Gender inequality comes from biological differences and social context [1]. Women need different treatment than men to prosperous the same rights. For example, in order to benefit from the right to work, women may need help and support from families and the societyin taking care of the child or doing their homework as a traditional duty.

Equity means pushing for a balance of power between men and women to create a truly justice society eventually [1]. Konigsbergstated that employed women, who are socially responsible, have the additional duty of housekeeping and childbirth. Men were unwilling share the burden of work in the home and thus employed women came home to a "second shift" of housework and childcare that increasing gender inequality [2]. These women have been suffered with a double burden which would endanger their health. women whose husbands were minimally involved in housework were 1.60 times more likely were under distress, 2.96 times more likely to be unpleasant with their husbands and 2.69 times more likely to be sad, compared to women whose husbands were highly involved in housework [3]. The responsibility of women has increased in family income provision but men's participation in family responsibilities has not increased, while the responsibility of the mother and the work of the house remains. In recent year the women's time in house work declined and the share of the men in housework increase. For example, Bianchi et al reported that in the US the highest decline in women house working occurs between 1965 and 1998-1999. At this time interval the men contribution in housework reached to 11 hours a week. Still women are estimated to do 1.6 times the amount of housework as men [4]. World Health Organization (WHO) reported that women will be more involved in workforce globally that entail great danger for their health [1]. Women who have been treated unfairly in working life and other social status may undergo to health risks. Gender inequality damages the mental and physical health of millions women worldwide. Employed women had more job insecurity, lower control, worse contractual working conditions and poorer selfperceived physical and mental health than men did. Women with a high housework overload had a higher prevalence of common mental 
disorders than women with a low overload [1]. In Iran, there was no accurate statistics about accompanying of men and women in house work and child care. Regarding our cultural status and logical context, it seems that the contribution of Iranian men in housework was lower than above reported values. Therefore, some degree of inequality and discrimination was exerted to employed women in Iran. Rezvani and Zanjanizade in 2015 reported that only 14 percent of 400 studied employed women in Mashhad were satisfied from work dividing at home [5]. Gender biological differences must be considered in work place. Government support measures for working women and encouraging men to participation, promoting women's position in various aspects of financial independence, increasing women's safety, eliminating discrimination, increasing the quality of women's participation in society, and increasing the presence of women in decision-making are very important women's health and must paid attention by the government and policymakers; because the heart of health development is the promotion of women's health.

\section{References}

1- Dakin M. Women and gender equity. WHO2018. Available: http://www.who.int/social_determinants/ themes/womenandgender/en/.2018

2- Konigsberg R D. Chore wars. Time2011; 178: 44-9.

3- Khawaja M, Habib RR. Husbands' involvement in housework and women's psychosocial health: findings from a population-based study in Lebanon. Am J Public Health2007; 97(5): 860-6.

4- Bianchi SM, Sayer LC, Mikkie MA, Robinson JP. Housework: who did, does or will do it, and how much does it matter? Social forces2012; 91(1): 55-63.

5- Rezvani M, Zanjanizadeh $H$. Investigation factors affecting work dividing in family. Socio-Psychological Study of Women2015; 12(4): 29-60.

Copyright $(2016$ ASP Ins. This open-access article is published under the terms of the Creative Commons Attribution-NonCommercial 4.0 International License which permits Share (copy and redistribute the material in any medium or format) and Adapt (remix, transform, and build upon the material) under the Attribution-NonCommercial terms. 